\title{
FTO Gene
}

National Cancer Institute

\section{Source}

National Cancer Institute. FT O Gene. NCI Thesaurus. Code C99468.

This gene is involved in the demethylation of nucleic acids. 